Article

\title{
Evolution of Phase Composition and Antibacterial Activity of Zr-C Thin Films
}

\author{
Katarzyna Mydłowska ${ }^{1, *(\mathbb{D})}$, Ewa Czerwińska ${ }^{1}$, Adam Gilewicz ${ }^{1}$, Ewa Dobruchowska ${ }^{1}{ }^{1}$, \\ Ewa Jakubczyk ${ }^{2}$, Lukasz Szparaga $^{1}$, Przemysław Ceynowa ${ }^{1}$ and Jerzy Ratajski ${ }^{1}$ \\ 1 Faculty of Mechanical Engineering, Koszalin University of Technology (KUT), Śniadeckich 2, \\ 75-453 Koszalin, Poland; ewa.czerwinska@tu.koszalin.pl (E.C.); adam.gilewicz@tu.koszalin.pl (A.G.); \\ ewa.dobruchowska@tu.koszalin.pl (E.D.); lukasz.szparaga@tu.koszalin.pl (Ł.S.); \\ przemyslaw.ceynowa@tu.koszalin.pl (P.C.); jerzy.ratajski@tu.koszalin.pl (J.R.) \\ 2 Centre for Engineering Materials, Mechanical Engineering Sciences, University of Surrey, Surrey, \\ Guildford GU2 7XH, UK; e.jakubczyk@surrey.ac.uk \\ * Correspondence: katarzyna.mydlowska@tu.koszalin.pl; Tel.: +48-94-348-65-62
}

Received: 26 January 2020; Accepted: 20 February 2020; Published: 25 February 2020

\begin{abstract}
The research presented in this article concerns $\mathrm{Zr}-\mathrm{C}$ coatings which were deposited on $304 \mathrm{~L}$ steel by reactive magnetron sputtering from the $\mathrm{Zr}$ target in an $\mathrm{Ar}-\mathrm{C}_{2} \mathrm{H}_{2}$ atmosphere at various acetylene flow rates, resulting in various atomic carbon concentrations in the coating. The article describes research covering the change in the antibacterial and anticorrosive properties of these coatings due to the change in their chemical and phase composition. The concentration of $C$ in the coatings varied from 21 to 79 at.\%. The coating morphology and the elemental distribution in individual coatings were characterized using field emission scanning electron microscopy with an energy-dispersive X-ray analytical system. X-ray diffraction and Raman spectroscopy were used to analyze their microstructure and phase composition. Parallel changes in the mechanical properties of the coatings were analyzed. Based on the obtained results, it was concluded that the wide possibility of shaping the mechanical properties of $\mathrm{Zr}-\mathrm{C}$ coatings in combination with relatively good antibacterial properties after exceeding 50 at.\% of carbon concentration in coatings and high protective potential of these coatings make them a good candidate for medical applications. In particular, corrosion tests showed the high anti-pitting potential of $\mathrm{Zr}-\mathrm{C}$ coatings in the environment of artificial saliva.
\end{abstract}

Keywords: thin films; zirconium carbide; antimicrobial properties; medical implants

\section{Introduction}

Metals and alloys are widely used in the production of medical implants for use in dentistry, cardiology, orthopedic fractures, etc. Titanium alloys, austenitic stainless steel and chromium-cobalt-nickel alloys are mainly used for implants. First of all, these materials must have adequate biocompatibility, i.e., they must not be irritating, toxic, allergic, inflammatory, mutagenic or carcinogenic to surrounding tissues [1,2]. For example, in the case of dental and orthodontic implants, some studies show that biofilms caused by attachment of bacteria are responsible for about $65 \%$ of infections such as periodontal disease and peri-implant diseases [3]. To prevent these adverse effects, surface treatments are used, among which the deposition of coatings by PVD and CVD methods are one of the ways to improve their mechanical and biological properties [4-8]. In particular, the coatings should fulfill a number of functions, such as bacterial resistance, i.e., resistance to adhesion and colonization of bacteria $[9,10]$. They should be biocompatible $[11]$, have adequate thrombogenicity $[12,13]$ in cardiac surgery applications and create a suitable diffusion barrier for elements causing allergic reactions in the case of deposition of coatings on medical steels $[4,14]$. Simultaneously, the coatings should have pitting 
corrosion resistance, a low coefficient of friction and wear resistance, high hardness and low Young's modulus [15-17]. The aforementioned range of properties by which coatings should be characterized is a function of many factors, the most important of which is the chemical composition of coatings and their structure (monolayers, multilayers, nanocomposites, gradient coatings, etc. [18]). In the case of antibacterial properties, due to the fact that the interaction of the material with bacteria is adhesive, the chemical activity is important (contact angle, free surface energy, etc.) and depends primarily on the chemical composition and type of bonds in the surface layer of coatings deposited on implants. The roughness of the surface is also taken into account.

Promising candidates meeting these requirements are thin coatings made of transition metal carbides. Among them, zirconium-carbide-based coatings are interesting due to their chemical, mechanical and electrical properties [19-22]. The microstructure and phase composition of these coatings are mainly influenced by the atomic concentration of carbon as well as the parameters of the coating deposition process $[23,24]$. Relatively significant possibilities of controlling properties are obtained due to the formation of free carbon in the amorphous form surrounding the grains of nanocrystalline carbide [25], although comparing to coatings based on transition metal nitrides, carbide coatings with higher carbon concentrations are characterized with lower hardness, however, production of coatings with a lower coefficient of friction is possible. Hence, by appropriately changing the phase composition and using the potential of carbon to combine into various structures, there are wide possibilities of shaping the properties of coatings based on $\mathrm{Zr}-\mathrm{C}$, which also inspire research on the perspectives of their application on medical implants $[4,26,27]$. In particular, in the studies presented in [4], $\mathrm{ZrC}$ coatings were deposited at different substrate temperatures $\left(25,200\right.$ and $\left.400{ }^{\circ} \mathrm{C}\right)$ on substrates of 316L steel. It has been shown that the surface energy, hydrophobicity and surface roughness have the greatest influence on the hemocompatibility of these coatings. The authors of [28] present research on the analysis of antibacterial activity and cell proliferation activity of $\mathrm{Zr}-\mathrm{C}-\mathrm{N}$ coating with different $C$ concentration deposited on titanium (Ti). Coatings with the highest $C$ concentration (22 at.\%) have been shown to increase the antibacterial ability against Staphylococcus aureus, but also meet the requirement for HGF (human gingival fibroblasts) biocompatibility. Tests of $\mathrm{CN}_{\mathrm{x}}$-doped $\mathrm{W}$, $\mathrm{Ti}$ and $\mathrm{Zr}$ coatings for antibacterial activity and wear are presented in [6]. It was shown that the $\mathrm{CN}_{\mathrm{x}}-\mathrm{Zr}$ coating, whose surface had the highest hydrophilicity, provided the best antibacterial effect. However, the $\mathrm{CN}_{\mathrm{x}}-\mathrm{Zr}$ coating showed lower wear resistance than the $\mathrm{CN}_{\mathrm{x}}-\mathrm{W}$ and $\mathrm{CNx}$-Ti coatings.

The research presented in this article concerns $\mathrm{Zr}-\mathrm{C}$ coatings which were deposited on $304 \mathrm{~L}$ steel by reactive magnetron sputtering from the $\mathrm{Zr}$ target in an $\mathrm{Ar}-\mathrm{C}_{2} \mathrm{H}_{2}$ atmosphere at various mass acetylene flow rates conditioning a specific carbon concentration in the coating. The evolution of phase composition of coatings was studied with increasing carbon concentration and the composition correlated with mechanical, antibacterial and corrosive properties. For comparison, these properties were also tested for $304 \mathrm{~L}$ steel without a coating. In particular, the correspondence between chemical and phase composition of coatings and biological properties was studied. Corrosion properties and contact angle were tested in an environment that simulates the oral cavity, i.e., artificial saliva, taking into account the possible application of $\mathrm{Zr}-\mathrm{C}$ coatings on orthodontic wires.

\section{Materials and Methods}

\subsection{Coating Deposition}

$\mathrm{Zr}-\mathrm{C}$ coatings deposited by pulsed, reactive magnetron sputtering on high-speed steel substrates were the object of research previously described by the authors in [17]. Coatings considered in this paper were deposited on $304 \mathrm{~L}$ medical steel substrates in the form of discs with a diameter of $32 \mathrm{~mm}$ and a thickness of $4 \mathrm{~mm}$ in the same deposition processes, methodology which has been described in detail in previous work [17]. The objects of research in this work are $\mathrm{Zr}-\mathrm{C}$ coatings with different carbon concentrations obtained at various acetylene mass flow rates during the deposition process. 
In addition, zirconium coatings deposited without carbon-carrier gas in the working chamber were tested for comparative purposes.

\subsection{Structural and Compositional Characterisation}

The surface morphology and the elemental distribution in individual coatings were characterized using field emission scanning electron microscopy (FESEM, JEOL, JSM-7100F) with an energy-dispersive X-ray analytical system (Thermo Fisher SEM-EDX).

The concentration of the individual elements in the deposited coatings was determined by wavelength-dispersive X-ray spectroscopy (WDX) using a Thermo Scientific's Magnaray system with an $\mathrm{X}$-ray microprobe working in a wave mode.

The microstructure of $\mathrm{Zr}-\mathrm{C}$ coatings was analyzed by means of $\mathrm{X}$-ray diffraction (XRD) using the conventional symmetrical Bragg-Brentano configuration $(\theta / 2 \theta)$ with the $\mathrm{Co}_{-} \mathrm{K}_{\alpha}$ radiation source on a DRON device. Further data processing was performed by HighScore Plus with ICDD PDF-4+ database software.

The analysis of the structure (type of bonds) of the carbon phase in $\mathrm{Zr}-\mathrm{C}$ coatings was carried out by Raman spectroscopy using Renishaw in Via with laser excitation of the $534 \mathrm{~nm}$ wavelength.

Chemical and phase composition of the coatings was determined by means of X-ray photoelectron spectroscopy (XPS) using a Kratos Axis Supra system with monochromatic Al K $\alpha 1,2$ radiation of energy $1486.6 \mathrm{eV}$. The calibration of the photoelectron spectrum was carried out with use of carbon $\mathrm{C} 1 \mathrm{~s}$ $(284.8 \mathrm{eV})$. The deconvolution of the XPS spectrum was performed through the fitting of peaks with the GL(30) function (Gauss and Lorenz functions at a ratio 30:70) and sigmoidal asymmetric function.

\subsection{Mechanical Evaluation}

Hardness measurements were performed by nanoindentation using the Fisherscope HM2000 nanoindenter equipped with the diamond Berkovich indenter. The load-depth indentation curves were obtained in the mode of the linear load increase up to $50 \mathrm{mN}$. The values of the hardness and the Young's modulus were determined based on the indentation curves using the Oliver-Pharr model [29].

\subsection{Microbiological Tests}

Four different species of microorganisms from the American Pure Culture Collection (Candida albicans ATCC 2091, Escherichia coli ATCC 25922, Staphylococcus aureus ATCC 25923 and Streptococcus mutans ATCC 35668) were used. The antimicrobial activity of the coatings was assessed by direct method based on the (BPR-ECHA-EU) regulation criteria (SN 195920-ASTM E2922), while the evaluation of antifungal activity was performed based on the SN 195921 standard. The fungus culture was carried out on Sabouraud medium, while the bacteria culture was on TSA medium. Test microorganisms were inoculated on the surface of the medium with a suspension concentration of $10^{8} \mathrm{cfu} / \mathrm{mL}(0.5 \mathrm{Mc}$ Farland); the test samples faced with coatings were placed into the medium after $20 \mathrm{~min}$ and incubated at $37^{\circ} \mathrm{C}$ for $48 \mathrm{~h}$. After incubation, the growth inhibition zone of the tested microorganisms was evaluated. The criterion for the assessment of fungicidal and bactericidal properties was the presence and size of the zone inhibiting the growth of the tested microorganisms. The tests were carried out in three repetitions for each tested sample and each tested microorganism.

To test the susceptibility of the surface of the coatings to microbial adhesion, a bacterial suspension with a density of $0.5 \mathrm{McF}$ arland was applied to the test specimens and incubated at $37^{\circ} \mathrm{C}$ for $24 \mathrm{~h}$. After culturing, the samples were washed three times with distilled water to remove nonadherent cells and then shaken for $15 \mathrm{~min}$ in distilled water. Afterwards, the coatings were dried and the $0.5 \mathrm{~cm}^{3}$ of benzidine bis (for observation of live cells) was applied to the surface and incubated for $120 \mathrm{~s}$. After rinsing in distilled water, $0.3 \mathrm{~cm}^{3}$ of propidium iodide (dead cell observation) was placed on the surface of the coatings for $120 \mathrm{~s}$ and again washed with water. After drying, the surfaces of the samples were observed using a fluorescence microscope (Motic BA 410 E M, MOTIC ASIA, Hong Kong). For each coating and the observed microorganism, two series of measurements were made and the final total 
number of microorganisms was the average of ten $1 \mathrm{~cm}^{2}$ fields of view calculated using the Motic Live Imaging (MOTIC ASIA, Hong Kong) module.

The results of microbial adhesion to the coatings were calculated in relation to the control sample (304L sample without coating) using the formula:

$$
\eta=\left(\left(\mathrm{N}_{0}-\mathrm{N}\right) / \mathrm{N}_{0}\right) \times 100 \%,
$$

where $\mathrm{N}$ represents the number of living/dead cells on the sample in $\mathrm{cfu} / \mathrm{cm}^{2}$ and $\mathrm{N}_{0}$ represents the number of living/dead cells on the uncoated 304L reference sample.

\subsection{The Wettability of Coating Surface and Corrosion Behavior}

The wettability of the coating surface was determined by measuring the static contact angles through the sessile drop method using F4 Goniometer by Rame-Hart Instrumental Co. Drops with a volume of approximately $4 \mu \mathrm{L}$ were deposited onto the investigated surfaces using a microsyringe. Fusayama-Meyer's artificial saliva, with the composition given in Table 1, was used as a test liquid. The contact angles were measured at 3-5 different points at the surface of each sample. The images were recorded over $300 \mathrm{~s}$ and analyzed using the DROPimage CA (Rame-Hart Instrumental Co) program.

Table 1. Chemical composition of Fusayama-Meyer's artificial saliva, pH 5.3.

\begin{tabular}{ccccccc}
\hline Compound & $\mathbf{K C l}$ & $\mathbf{N a C l}$ & $\mathbf{C a C l}_{\mathbf{2}} \times \mathbf{2} \mathbf{H}_{\mathbf{2}} \mathbf{O}$ & $\mathbf{N a H}_{\mathbf{2}} \mathbf{P O}_{\mathbf{4}} \times \mathbf{2} \mathbf{H}_{\mathbf{2}} \mathbf{O}$ & $\mathbf{N a}_{\mathbf{2}} \mathbf{S} \times \mathbf{9} \mathbf{H}_{\mathbf{2}} \mathbf{O}$ & Urea \\
\hline Concentration $(\mathrm{g} / \mathrm{L})$ & 0.400 & 0.400 & 0.906 & 0.690 & 0.005 & 1.000 \\
\hline
\end{tabular}

The corrosion behavior of substrate/coating systems was evaluated by potentiodynamic polarization tests, which were carried out using an ATLAS 0531 Electrochemical Unit (Atlas-Sollich, Poland). Conventional electrochemical three-electrode cell was used with a sample with the active area of $0.292 \mathrm{~cm}^{2}$ as the working electrode, saturated calomel electrode (SCE, $\mathrm{Hg} / \mathrm{Hg}_{2} \mathrm{Cl}_{2} / \mathrm{KCl}$ ) as the reference electrode and a platinum sheet as counter electrode. The electrolyte was Fusayama-Meyer artificial saliva. Polarization tests were carried out in a temperature of $25 \pm 1{ }^{\circ} \mathrm{C}$ at the scan rate of $0.001 \mathrm{~V} / \mathrm{s}$. Prior to polarization, the samples were kept in contact with the electrolyte for $1 \mathrm{~h}$ at open circuit conditions. Measurements were repeated until obtaining three similar results (polarization curves). Corrosion potential ( $\left.\mathrm{E}_{\mathrm{corr}}\right)$, corrosion current density $\left(\mathrm{i}_{\mathrm{corr}}\right)$ and polarization resistance $\left(\mathrm{R}_{\mathrm{pol}}\right.$ - $\mathrm{a}$ value inversely proportional to $i_{\text {corr }}$ ) were estimated by the Tafel extrapolation method. Since the anodic curves were influenced by passivation reactions, only the cathodic curves were used to determine $\mathrm{i}_{\text {corr }}$, according to [30].

\section{Results}

\subsection{Chemical Composition}

To determine the effect of acetylene mass flow rate on the chemical composition of the deposited coating, wavelength-dispersive X-ray spectroscopy (WDX) tests were carried out. Table 2 summarizes the results of the tests, i.e., the average concentrations of elements in individual coatings.

Table 2. Chemical composition of the $\mathrm{Zr}-\mathrm{C}$ coatings.

\begin{tabular}{cccc}
\hline $\mathbf{C}_{\mathbf{2}} \mathbf{H}_{\mathbf{2}}$ Volumetric Flow Rate, sccm & $\mathbf{C}$, at. $\%$ & $\mathbf{Z r}$, at. $\%$ & $\mathbf{O}, \mathbf{H}$ and Others, at. $\%$ \\
\hline 0 & $\sim 0.0$ & 91.8 & 8.2 \\
1.5 & 20.7 & 71.6 & 7.7 \\
3.5 & 52.9 & 43.7 & 3.4 \\
4.5 & 63.3 & 33.0 & 3.7 \\
6.5 & 79.0 & 18.9 & 2.1 \\
\hline
\end{tabular}


It has been proven that in coatings deposited using volumetric flow rates between $1.5-6.5 \mathrm{sccm}$, the carbon concentration increases linearly from around 20 to 80 at.\%.

In order to determine the chemical composition (chemical bonds) of the surface layer of deposited coatings, important from the point of view of biological properties, an XPS test was performed.

As expected, among the atoms identified on the surface of the coatings, the main share is zirconium and carbon. As mentioned above, the samples after the deposition process were in the ambient atmosphere, and therefore a significant amount of oxygen atoms is also observed on their surface. Figure 1 shows high resolution $\mathrm{Zr} 3 \mathrm{~d}, \mathrm{O} 1 \mathrm{~s}$ and $\mathrm{C} 1 \mathrm{~s}$ spectra. The positions of individual peaks in the spectra obtained as a result of their deconvolution with Gaussian curves are given in Table 3. The $\mathrm{Zr} 3 \mathrm{~d}$ spectrum for each coating (Figure 1a) can be deconvolved into four main peaks of about 180, 182, 183 and $185 \mathrm{eV}$. The first two refer to $\mathrm{Zr}-\mathrm{C}$ bonds, while the others are derived from $\mathrm{Zr}-\mathrm{O}$ bonds in connection with spin-orbit doublets (i.e., $\mathrm{Zr} 3 \mathrm{~d}^{5 / 2}$ and $\mathrm{Zr} \mathrm{3d^{3/2 }}$ ) separated by energy difference [31]. For coatings with a higher carbon concentration (63 and 79 at.\%), zirconium carbide is by far the dominant phase. According to the literature [32], binding energy of metallic zirconium is typically around $178.5 \mathrm{eV}$. The location of the maximum main peak in the $\mathrm{Zr} 3 \mathrm{~d}$ spectrum for the coating at 21 at.\% $C$ between energies typical for $\mathrm{Zr}-\mathrm{C}$ bond and $\mathrm{Zr}-\mathrm{Zr}$ as well as the shift of the peak assigned to $\mathrm{Zr}-\mathrm{C}$ in the $\mathrm{C}$ 1s spectrum for this coating towards lower binding energies suggests the presence of some kind of intermediate phase, not metallic zirconium itself. At lower carbon concentrations (21 and 53 at.\%), a relatively high proportion of zirconium oxide is observed. This is due to the high reactivity of zirconium, which in contact with air is oxidized to form stable, compact oxides on the surface of the material. In the $\mathrm{O} 1 \mathrm{~s}$ (Figure 1b) spectrum, the dominant peak for all coatings is a peak of about $530.5 \mathrm{eV}$ identified as $\mathrm{Zr}-\mathrm{O}$ bond. Other peaks come from oxygen adsorbed on the surface and contamination by organic compounds.

In the case of spectrum C 1s (Figure 1c) for coatings from 53 at. $\% \mathrm{C}$ inclusive, four peaks can be distinguished. The peak at about $284.8 \mathrm{eV}$ is characteristic for $\mathrm{C}-\mathrm{C}$ bonds. The peak at about $286.5 \mathrm{eV}$, of lower intensity, originates from $\mathrm{C}-\mathrm{O}$ bonds in the alcohol and ester group (surface impurities). The $\sim 282 \mathrm{eV}$ peak is characteristic for $\mathrm{Zr}-\mathrm{C}$ binding. An additional peak of $283 \mathrm{eV}$ is also present for these three coatings. The presence of an additional peak between the peaks derived from $\mathrm{Me}-\mathrm{C}$ and $\mathrm{C}-\mathrm{C}$ bonds has been observed earlier in $\mathrm{Zr}$, Ti and $\mathrm{Nb}$ carbide coatings [33]. It is attributed to the occurrence of a phase in which carbon atoms are partially bonded to metal and carbon simultaneously (atoms on the border of metal carbide and amorphous carbon phases) and therefore is marked with a symbor Me-C*. For the two coatings with the highest carbon concentrations (63 and 79 at.\%), this peak becomes dominant over $\mathrm{Zr}$-C. In addition, with increasing carbon concentration in the coating, the peak from $\mathrm{Zr}-\mathrm{C}$ shifts towards higher binding energies. This may indicate an increase in the proportion of the amorphous carbon phase and that the system is transformed into the $\mathrm{MeC} / \mathrm{a}-\mathrm{C}$ nanocomposite [34].

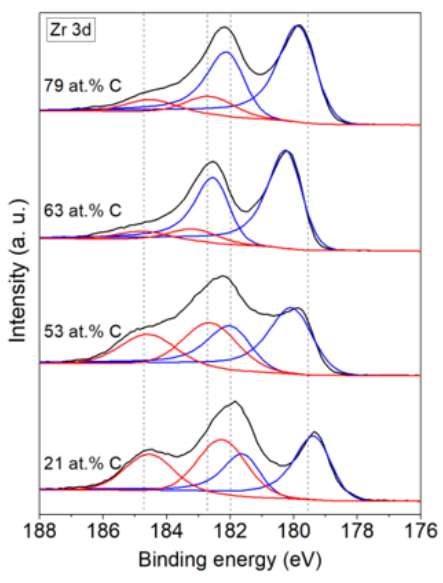

(a)

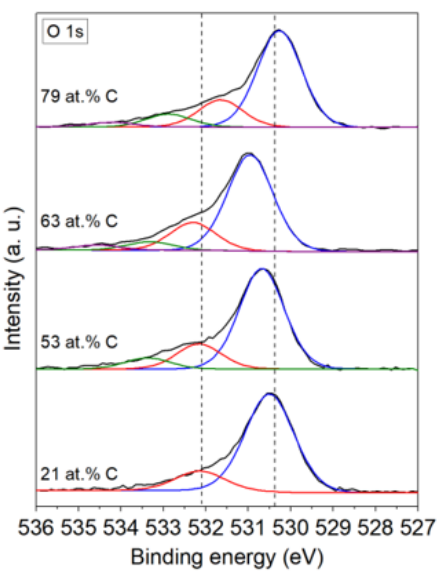

(b)

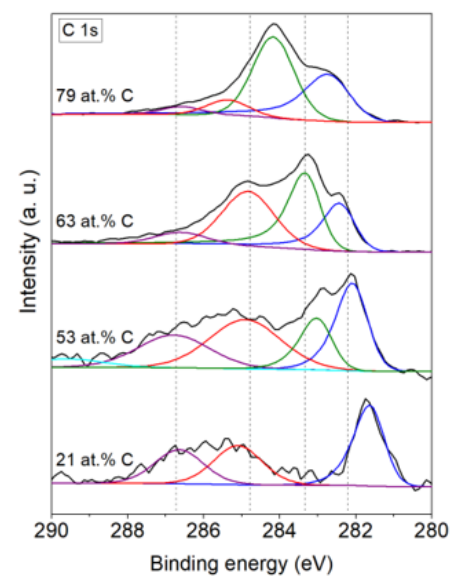

(c)

Figure 1. XPS spectra of Zr-C coatings of various carbon concentrations (a) Zr 3d, (b) O 1s, (c) C 1s. 
Table 3. Binding energies calculated from the deconvolved XPS spectra.

\begin{tabular}{|c|c|c|c|c|c|c|c|c|c|}
\hline & \multicolumn{3}{|c|}{$\mathrm{Zr}$ (3d) } & \multicolumn{3}{|c|}{$\mathrm{O}(1 \mathrm{~s})$} & \multicolumn{3}{|c|}{$C(1 s)$} \\
\hline Type of Coating & Phase & at. $\%$ & B.E. $(\mathrm{eV})$ & Phase & at. $\%$ & B.E. $(\mathrm{eV})$ & Phase & at. $\%$ & B.E. $(\mathrm{eV})$ \\
\hline \multirow{4}{*}{21 at. $\% \mathrm{C}$} & $\mathrm{ZrC}$ & 45 & $179.4\left(3 d^{5 / 2}\right)$ & $\mathrm{ZrO}_{2}$ & 83.3 & 530.5 & $\mathrm{ZrC}$ & 39.72 & 281.6 \\
\hline & & & $181.6\left(3 d^{3 / 2}\right)$ & $\mathrm{O}$ ads. & 16.7 & 532.2 & C-C & 32.16 & 285.1 \\
\hline & $\mathrm{ZrO}_{2}$ & 55 & $182.3\left(3 d^{5 / 2}\right)$ & & & & $\mathrm{C}-\mathrm{O}-\mathrm{C}, \mathrm{C}-\mathrm{OH}$ & 28.12 & 286.7 \\
\hline & & & $184.5\left(3 \mathrm{~d}^{3 / 2}\right)$ & & & & & & \\
\hline \multirow{5}{*}{53 at. $\%$ C } & $\mathrm{ZrC}$ & 52.5 & $180.1\left(3 d^{3 / 2}\right)$ & $\mathrm{ZrO}_{2}$ & 73.6 & 530.7 & $\mathrm{ZrC}$ & 24.64 & 282.1 \\
\hline & & & $182.0\left(3 \mathrm{~d}^{5 / 2}\right)$ & $\mathrm{O}$ ads. & 18.3 & 532.2 & $\mathrm{ZrC} *$ & 14.6 & 283 \\
\hline & $\mathrm{ZrO}_{2}$ & 47.5 & $182.6\left(3 \mathrm{~d}^{3 / 2}\right)$ & & 8.1 & 533.4 & $C-C$ & 33.18 & 284.9 \\
\hline & & & $184.6\left(3 d^{5 / 2}\right)$ & & & & $\mathrm{C}-\mathrm{O}-\mathrm{C}, \mathrm{C}-\mathrm{OH}$ & 27.57 & 286.8 \\
\hline & & & & & & & & & 289.6 \\
\hline \multirow{4}{*}{63 at. $\%$ C } & $\mathrm{ZrC}$ & 84.2 & $180.3\left(3 d^{5 / 2}\right)$ & $\mathrm{ZrO}_{2}$ & 70.1 & 531 & $\mathrm{ZrC}$ & 19.95 & 282.43 \\
\hline & & & $182.5\left(3 \mathrm{~d}^{3 / 2}\right)$ & $\mathrm{O}$ ads. & 20.2 & 532.3 & $\mathrm{ZrC}^{*}$ & 31.94 & 283.34 \\
\hline & $\mathrm{ZrO}_{2}$ & 15.8 & $183.1\left(3 d^{5 / 2}\right)$ & & 6.1 & 533.3 & $C-C$ & 39.55 & 284.83 \\
\hline & & & $184.8\left(3 \mathrm{~d}^{3 / 2}\right)$ & & 3.6 & 534.6 & $\mathrm{C}-\mathrm{O}-\mathrm{C}, \mathrm{C}-\mathrm{OH}$ & 8.56 & 286.61 \\
\hline \multirow{4}{*}{79 at. $\%$ C } & $\mathrm{ZrC}$ & 79.2 & $179.9\left(3 d^{5 / 2}\right)$ & $\mathrm{ZrO}_{2}$ & 68.5 & 530.3 & $\mathrm{ZrC}$ & 31.7 & 282.7 \\
\hline & & & $182.1\left(3 \mathrm{~d}^{3 / 2}\right)$ & $\mathrm{O}$ ads. & 19.2 & 531.7 & $\mathrm{ZrC} *$ & 53.2 & 284.2 \\
\hline & $\mathrm{ZrO}_{2}$ & 20.8 & $182.6\left(3 d^{5 / 2}\right)$ & & 9.1 & 532.9 & C-C & 10 & 285.4 \\
\hline & & & $184.5\left(3 \mathrm{~d}^{3 / 2}\right)$ & & 3.2 & 534.2 & $\mathrm{C}-\mathrm{O}-\mathrm{C}, \mathrm{C}-\mathrm{OH}$ & 5.1 & 286.6 \\
\hline
\end{tabular}

\subsection{Coating Morphology}

The effect of $C$ concentration on the microstructure of chosen coatings is illustrated in Figure 2a. In addition, Figure $2 \mathrm{~b}-\mathrm{d}$ shows the results of EDX mapping, which aimed to examine the degree of uniformity in the distribution of elements on the coating surface. It can be seen that the grain boundaries are clearly observed in the SEM micrographs (Figure 2a). Maps clearly show that $\mathrm{Zr}, \mathrm{C}$ and $\mathrm{O}$ are evenly distributed on the surface of each coating. As mentioned in Section 3.1, the presence of oxygen is associated with the oxidation of the surface of the coatings stored in the ambient atmosphere after the deposition process or with the process conditions themselves.
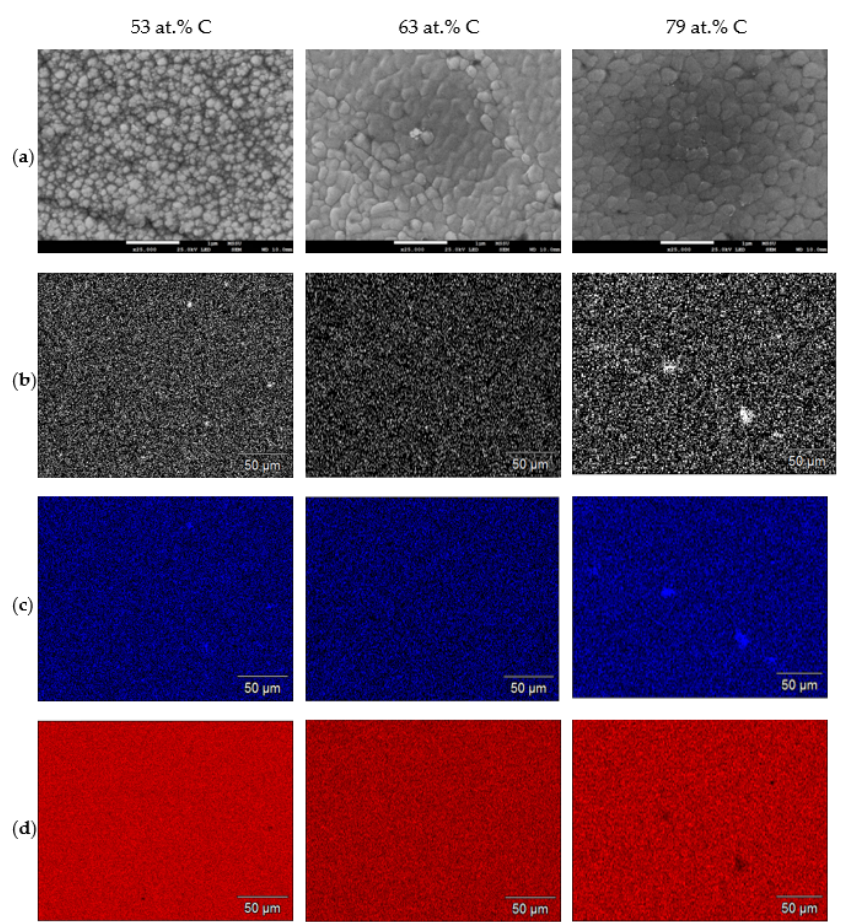

Figure 2. (a) SEM micrographs of the surfaces of coatings. (b-d) SEM-EDX mapping with a visible element distribution on the surface of samples: (b) O, (c) C, (d) $\mathrm{Zr}$. 
Based on the results of the EDX mapping analysis taken from the cross section of the samples, two layers can be distinguished (Figures 3 and 4). The first layer in direct contact with stainless steel (Zr adhesive layer) consistently has $300 \mathrm{~nm}$ thickness. The next (specific layer) is a mixture of $\mathrm{Zr}$ and $\mathrm{C}$, in which both elements are evenly distributed in its volume.

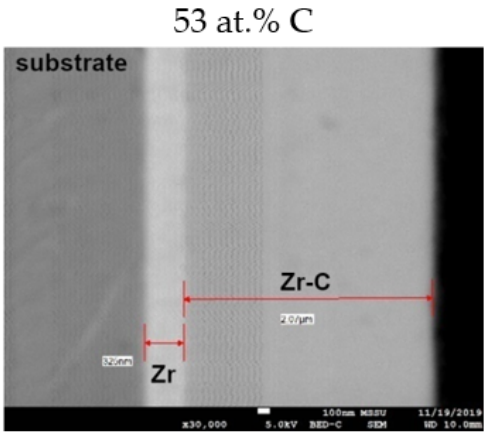

(a)

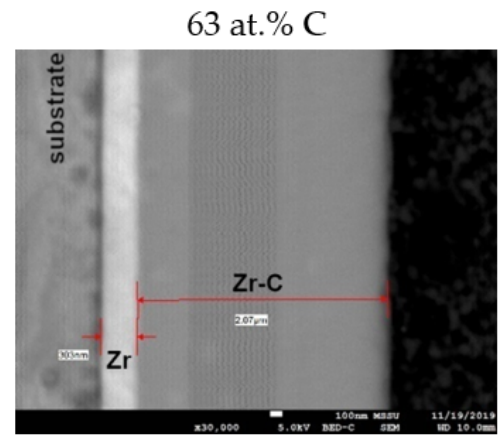

(b)

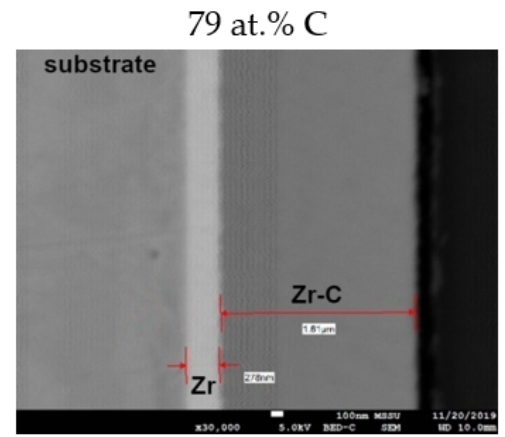

(c)

Figure 3. Backscattered electron (BSE) cross-sectional micrograph of samples (a) Zr-C with 53 at.\% C, (b) $\mathrm{Zr}-\mathrm{C}$ with 63 at.\% C, (c) Zr-C with 79 at.\% C.

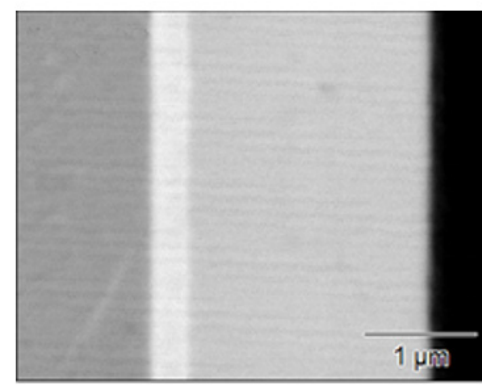

(a)

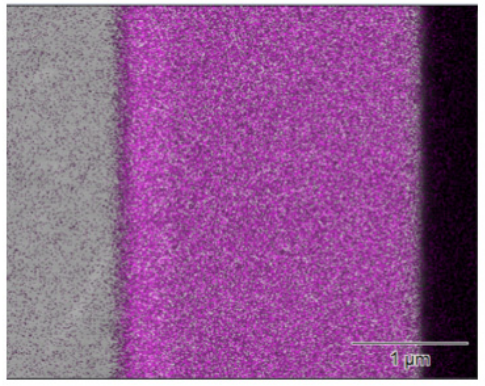

(b)

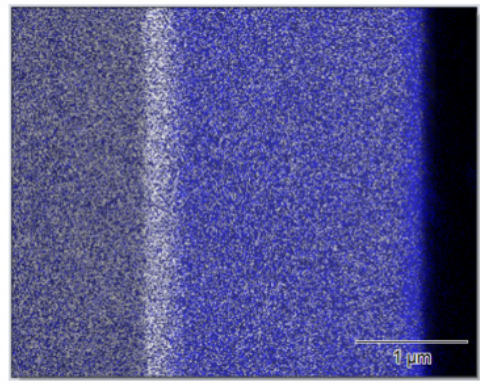

(c)

Figure 4. (a) Cross-sectional micrograph for sample with 53 at.\% C, with (b) an example of mapping distribution of $\mathrm{C}$ and (c) an example of mapping distribution of $\mathrm{Zr}$.

\subsection{Phase Composition}

\subsubsection{X-ray Diffraction}

Based on the analysis of X-ray diffraction patterns (Figure 5), obtained using conventional Bragg-Brentano geometry, it appears that the phase composition of the coatings changes radically with increasing carbon concentration, similarly to Ti-C coatings [35]: from the coating dominated by $\mathrm{Zr}$ for low carbon concentration (21 at.\%) through the intermediate $\mathrm{Zr}-\mathrm{ZrC}$ phases to the nanocomposite coating composed of zirconium carbide in an amorphous hydrogenated carbon matrix for the highest carbon concentration (79 at.\%).

These conclusions resulting from the analysis of registered X-ray diffractograms correspond with coating tests using XPS (Section 3.1). In particular, according to the PDF-4+ ICDD database, for a coating with a carbon concentration of 21 at.\%, the peak with the highest intensity comes from the $\mathrm{ZrC}$ phase (Ref. No. 04-019-3519) or from the $\mathrm{ZrC}_{0.2}$ phase (Ref. No. 04-002-0154). At carbon concentrations of 63 and 79 at.\%., the intensity of the main diffraction peak $\operatorname{ZrC}(111)$ decreases. At the same time, the width of the peak increases. This is due to the reduction of the $\mathrm{ZrC}$ phase content in the coating with simultaneous reduction of the $\mathrm{ZrC}$ crystallite size. In turn, the diffraction peaks from the $\mathrm{Zr}$ phase visible on the diffraction pattern, in the case of the coating with the highest carbon concentration, are derived from the $\mathrm{Zr}$ adhesive layer [17]. 


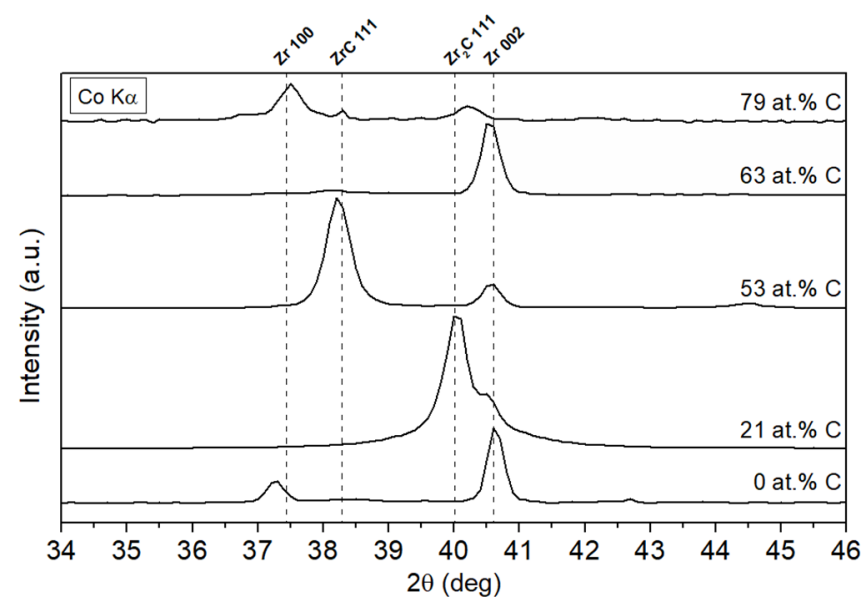

Figure 5. X-ray diffractograms of $\mathrm{Zr}-\mathrm{C}$ coatings at various concentrations of carbon.

\subsubsection{Raman Spectroscopy}

Raman spectroscopy was used to determine the carbon structure ( $\mathrm{sp}^{2}$ and $\mathrm{sp}^{3}$ bond ratio) in the coatings. For this purpose, Raman spectra were deconvolved with two Gaussian curves, as shown in Figure 6. Peaks were obtained with maximum positions of $\sim 1580 \mathrm{~cm}^{-1}$ and $\sim 1350 \mathrm{~cm}^{-1}$, referred to as peak $G$ and peak D, respectively [36].

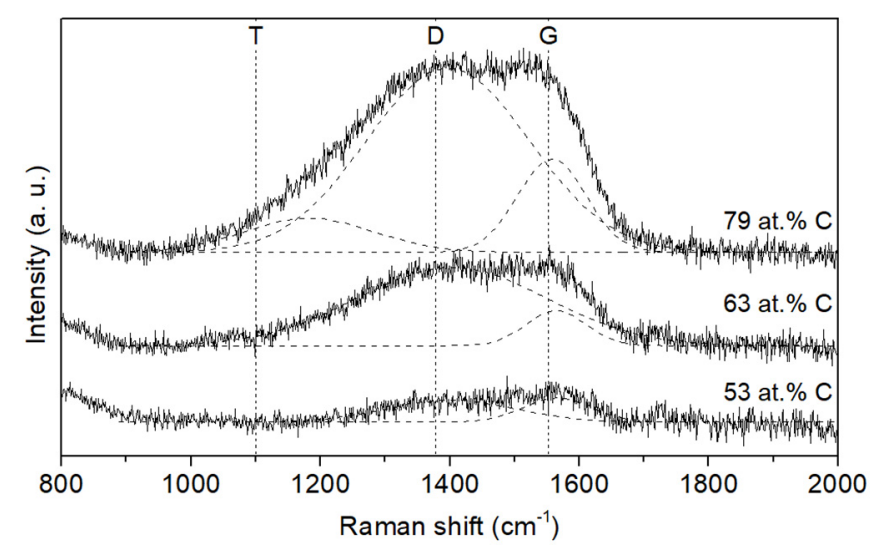

Figure 6. Raman spectra for tested coatings.

A so-called T peak (about $1100 \mathrm{~cm}^{-1}$ ) also appears for coatings with the highest carbon concentration. According to [37], this peak corresponds to the $\mathrm{C}-\mathrm{C} \mathrm{sp}{ }^{3}$ vibration density of states (VDOS). Table 4 summarizes the calculated $I(D) / I(G)$ ratios (integrated intensities of $D$ and $G$ peaks) as well as the location of the maximum of $G$ peak for each coating. According to the model proposed in [37], it can be stated that the coatings do not have a graphite structure, as evidenced by the location of the $G$ peak below $1580 \mathrm{~cm}^{-1}$, which is typical for polycrystalline graphite. This location, together with values of $\mathrm{I}(\mathrm{D}) / \mathrm{I}(\mathrm{G})$ ratio above 3.0, indicate that carbon is in amorphous form with a predominant share of $\mathrm{sp}^{2}$ hybridization bonds [17,37]. The maximum of this ratio for the coating by 63 at. $\%$, with the unchanged position of peak $\mathrm{G}$, may indicate the largest share of $\mathrm{sp}^{2}$ bonds in the carbon phase of this coating. 
Table 4. Analysis of Raman spectra for tested coatings.

\begin{tabular}{ccc}
\hline C (at.\%) & I(D)/I(G) & G Peak Position $\left(\mathbf{c m}^{-\mathbf{1}}\right)$ \\
\hline 53 & $3.08 \pm 0.13$ & $1577.1 \pm 0.42$ \\
63 & $4.5 \pm 0.08$ & $1575.4 \pm 0.35$ \\
79 & $3.91 \pm 0.09$ & $1575.1 \pm 0.33$ \\
\hline
\end{tabular}

\subsection{Mechanical Properties}

In Figure 7a, the hardness of the coatings depending on the concentration of carbon atoms is shown. It can be seen that the hardness of coatings changes dynamically as the concentration of carbon increases. At 21 at.\% $\mathrm{C}$, the hardness is $8 \mathrm{GPa}$, and it increases to almost $23 \mathrm{GPa}$ near the stoichiometric composition. After exceeding 50 at.\% C, it gradually decreases, and at a concentration of 79 at.\% C it reaches $15 \mathrm{GPa}$. The Young's modulus is characterized by the analogous nature of the changes (Figure 7b). According to the interpretation in [17] regarding Ti-C coatings, the increase in hardness is caused by a higher content of the carbide phase in the hard coating and increased concentration of carbon diffused into the interstitial sites of the carbide lattice [17]. Then, based on the analysis of X-ray diffraction patterns (Figure 5), it can be seen that after exceeding the concentration of 50 at.\% $\mathrm{C}$ in $\mathrm{Zr}-\mathrm{C}$ coatings, the participation of zirconium carbide phase decreases, which corresponds to a decrease in hardness and Young's modulus.

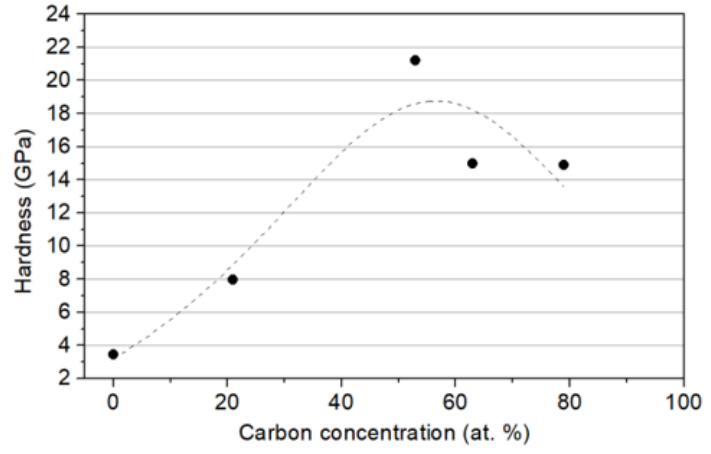

(a)

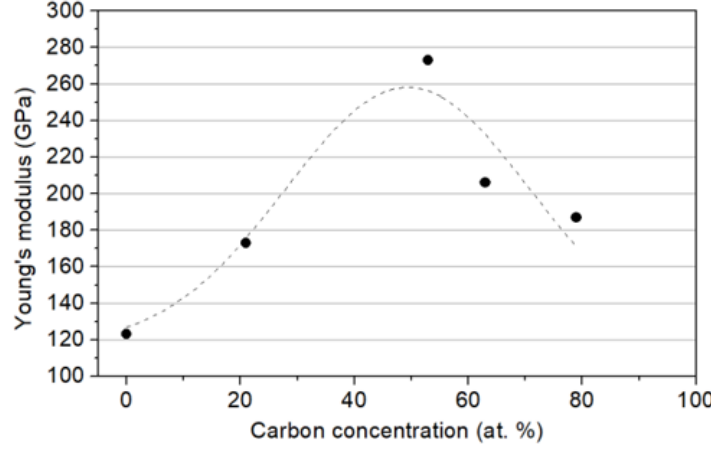

(b)

Figure 7. (a) Hardness, (b) Young's modulus of deposited coatings depending on carbon concentration.

\subsection{Antibacterial Properties}

\subsubsection{Static Zone of Inhibition}

Four species of microorganisms from the American Pure Culture Collection (Candida albicans ATCC 2091, Escherichia coli ATCC 25922, Staphylococcus aureus ATCC 25923 and Streptococcus mutans ATCC 35668) were used. The selected strains are representative of the peri-implant environment. The criterion for the assessment of fungicidal and bactericidal properties was the presence and size of the zone inhibiting the growth of microorganisms used for research.

According to the results presented in Figures 8 and 9, a 304L steel sample without coating does not create a zone of inhibition for all tested bacterial strains. This zone also does not form on samples with a $\mathrm{Zr}$ coating and a $\mathrm{Zr}-\mathrm{C}$ coating with a carbon concentration of 21 at. $\%$ for Candida albicans. For all other bacteria, zones of inhibition are formed for the samples regardless of the carbon concentration in the coating. 
Candida albicans Escherichia coli Staphylococcus aureus Streptococcus mutans
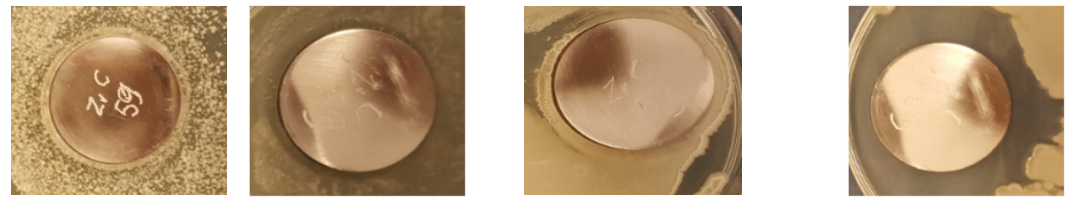

Figure 8. Antibacterial activity of the sample coated with $\mathrm{Zr}-\mathrm{C}(63$ at. $\% \mathrm{C})$ coating against bacterial strains based on the inhibition zone test.

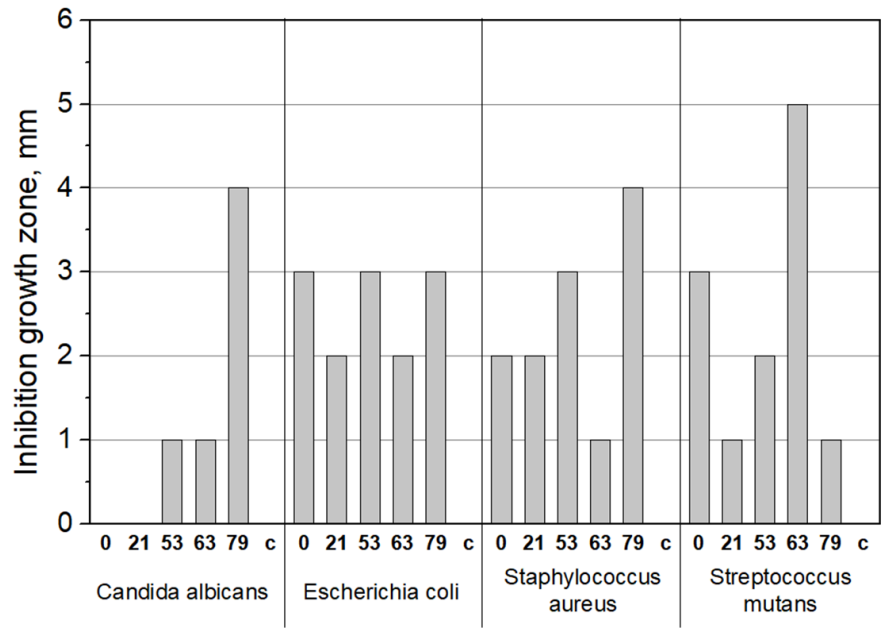

Figure 9. Growth inhibition zones of the bacterial strains in presence of the $\mathrm{Zr}-\mathrm{C}$ coated samples.

\subsubsection{Numbers of Live and Dead Cells}

In the case of living cells (Figure 10), the number of Candida albicans cells on the $\mathrm{Zr}$ coating and the coating with 21 at.\% C exceeds the amount of these cells on a 304L steel sample without a coating. The same applies to the $\mathrm{Zr}$ coating in the case of Escherichia coli bacterial cells. On coatings with a carbon concentration of 53 at.\% and higher, a lower relative number of live cells (Equation (1)) is observed relative to the uncoated sample. Among the tested coatings differing in the carbon concentration, there is a coating with a concentration of $\sim 63$ at. $\%$ on which a relatively small number of living cells is observed for all bacteria used in the study (according to Equation (1), the higher the bar, the smaller the number of cells).

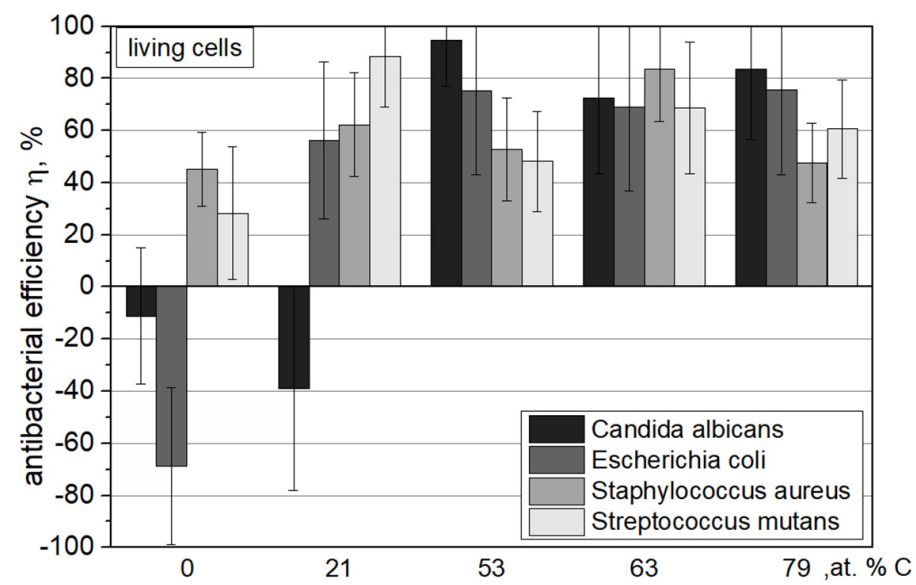

Figure 10. The relative number $\left(\mathrm{cfu} / \mathrm{cm}^{2}\right)$ of living bacterial cells on the $\mathrm{Zr}-\mathrm{C}$ coated samples relative to the number of living bacterial cells on the uncoated $304 \mathrm{~L}$ sample. 
In the case of dead cells, a similar tendency is observed regarding the number of cells as in the case of living cells (Figure 11). That is, for coatings with a carbon concentration exceeding 53 at.\%, the number of dead cells for all the bacteria used in the experiment is significantly reduced compared to the uncoated sample. This effect was demonstrated by calculating the average antibacterial efficiency of the tested coatings in relation to all considered strains (Figure 12).

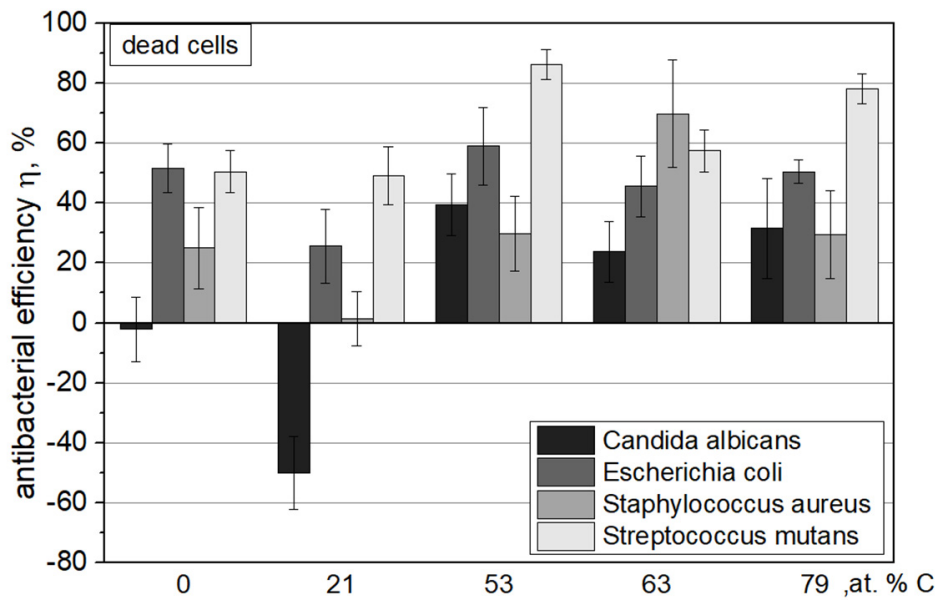

Figure 11. The relative number $\left(\mathrm{cfu} / \mathrm{cm}^{2}\right)$ of dead bacterial cells on the $\mathrm{Zr}-\mathrm{C}$ coated samples relative to the number of dead bacterial cells on the uncoated 304L sample.

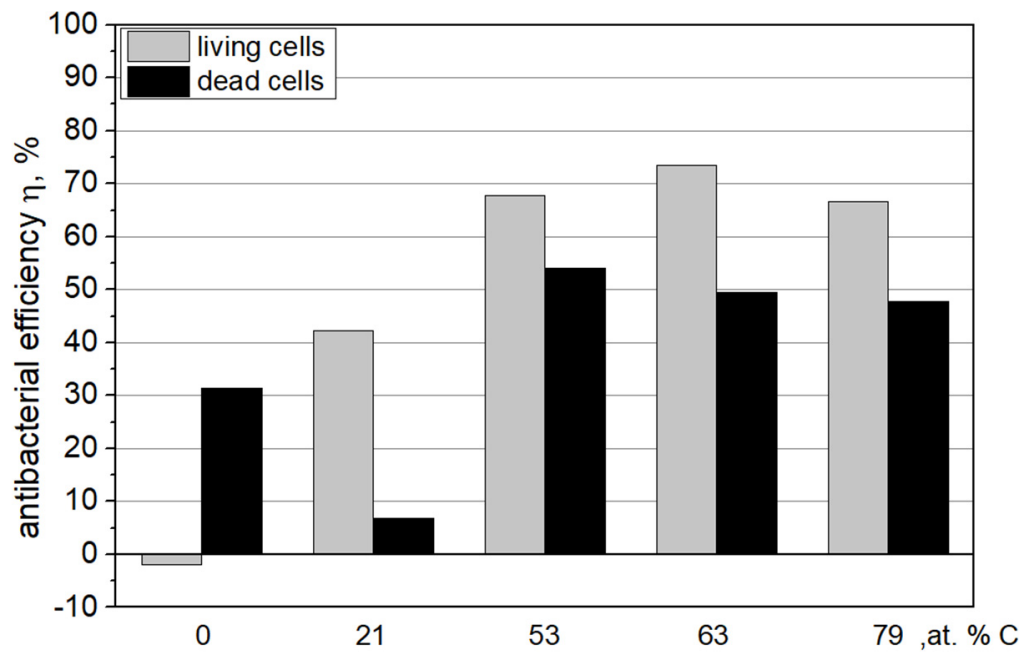

Figure 12. The relative average number $\left(\mathrm{cfu} / \mathrm{cm}^{2}\right)$ of living and dead bacterial cells for all bacterial strains on the $\mathrm{Zr}-\mathrm{C}$ coated samples relative to the number of bacterial cells on control sample.

\subsubsection{Contact Angle}

Microbial adhesion to the surface of the biomaterial depends on the surface properties of the microbial cell, the properties of the liquid surrounding the material and the surface properties of the material such as hydrophobicity/hydrophilicity and free surface energy. It has been shown in the literature that the formation of dental plaque in the human mouth is significantly reduced on hydrophobic surfaces relative to hydrophilic surfaces [38,39]. One of the reasons may be the fact that hydrophilic bacteria inhabiting the oral cavity tend to be surrounded by an aqueous medium such as saliva, which easily breaks away from the more hydrophobic surface of the biomaterial [39]. For this reason, an important factor in assessing the potential antibacterial properties of the coating is to study its hydrophobic properties by determining the contact angle. The results of measuring the contact angle of coatings and uncoated steel with the artificial saliva solution are shown in Table 5. 
Table 5. Contact angle of 304L steel substrate, bare and coated with Zr-C, with Fusayama-Meyer's artificial saliva.

\begin{tabular}{ccc}
\hline \multirow{2}{*}{ Sample } & Contact Angle After 30 s & Contact Angle After 300 s \\
\cline { 2 - 3 } & $\left.\mathbf{(}^{\circ}\right)$ & $\left.{ }^{\circ}\right)$ \\
\hline 304L & $87.0 \pm 0.7$ & $80.0 \pm 0.8$ \\
304L/Zr & $69.1 \pm 0.3$ & $56.0 \pm 1.7$ \\
304L/Zr-C-21 at.\% C & $73.2 \pm 1.4$ & $59.8 \pm 1.3$ \\
304L/Zr-C-53 at.\% C & $94.3 \pm 0.3$ & $86.7 \pm 0.5$ \\
304L/Zr-C-63 at.\% C & $99.2 \pm 0.4$ & $92.7 \pm 0.8$ \\
304L/Zr-C-79 at.\% C & $97.1 \pm 0.4$ & $89.5 \pm 1.7$ \\
\hline
\end{tabular}

Coatings deposited at a acetylene flow rate of $3.5 \mathrm{sccm}$ and above showed a higher contact angle than uncoated 304L steel. Given that the contact angle is a measure of hydrophobicity, it can be concluded that surfaces coated with $\mathrm{Zr}-\mathrm{C}$ coatings above 50 at. $\% \mathrm{C}$ are more hydrophobic than surfaces of uncoated $304 \mathrm{~L}$ steel. The highest contact angle was observed for the surface of the coating with a concentration above 60 at. $\%$ C $\left(99.2^{\circ}\right)$.

\subsection{Corrosion Properties}

In order to determine the protective properties of $\mathrm{Zr}-\mathrm{C}$ coatings, potentiodynamic tests were carried out in the solution of artificial saliva. Potentiodynamic curves for the substrate/Zr-C coating systems with different concentrations of carbon and for the uncoated substrate are shown in Figure 13. Values of determined corrosion current density $\left(\mathrm{i}_{\mathrm{corr}}\right)$, corrosion potential $\left(\mathrm{E}_{\mathrm{corr}}\right)$, polarization resistance $\left(R_{\text {pol }}\right)$, breakdown potential $\left(R_{b}\right)$ and the slope of the cathodic curve $\left(-b_{c}\right)$ are shown in Table 6 .

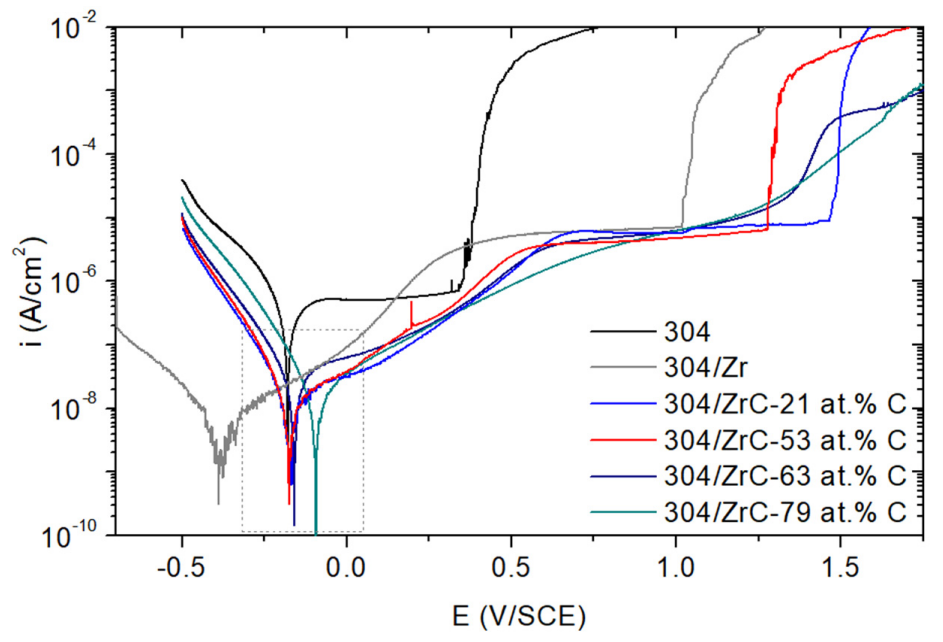

Figure 13. Polarization curves obtained for 304L steel substrate and substrate-coating systems in Fusayama-Meyer's artificial saliva.

Table 6. Electrochemical parameters characterizing corrosion processes of 304L steel substrate, bare and coated, in Fusayama-Meyer's artificial saliva.

\begin{tabular}{|c|c|c|c|c|c|c|}
\hline Sample & $E_{\text {corr }}$ & $i_{\text {corr }}$ & $-b_{\mathrm{c}}$ & $R_{\text {pol }}$ & $E_{\mathrm{b}}$ & $\begin{array}{c}\text { Protective } \\
\text { Efficiency [\%] }\end{array}$ \\
\hline $304 \mathrm{~L}$ & $0.191 \pm 0.019$ & $(827 \pm 40) \times 10^{-9}$ & $0.187 \pm 0.012$ & $(98 \pm 3) \times 10^{3}$ & $0.350 \pm 0.022$ & \\
\hline 304L/Zr-C-21 at.\% C & $0.162 \pm 0.016$ & $(27.76 \pm 7.25) \times 10^{-9}$ & $0.115 \pm 0.031$ & $(1.93 \pm 0.52) \times 10^{6}$ & $1.403 \pm 0.033$ & 96.6 \\
\hline 304L/Zr-C-53 at. \% C & $0.161 \pm 0.010$ & $(20.41 \pm 0.81) \times 10^{-9}$ & $0.115 \pm 0.004$ & $(1.82 \pm 0.55) \times 10^{6}$ & $1.219 \pm 0.154$ & 97.5 \\
\hline 304L/Zr-C-63 at.\% C & $0.157 \pm 0.007$ & $(41.29 \pm 5.07) \times 10^{-9}$ & $0.161 \pm 0.017$ & $(1.11 \pm 0.09) \times 10^{6}$ & - & 95.0 \\
\hline
\end{tabular}


The lowest corrosion potential among all tested samples (lower than steel) shows a sample with a zirconium coating. This is due to the greater reactivity of zirconium to alloying steel components resulting in rapid surface oxidation. The passive layer formed on the surface is very compact and provides effective protection against electrolytes (a clear passive area, the lowest corrosive current among the tested). The passive layer remains stable until reaching the breakdown potential of $1.175 \mathrm{~V}$. The tests also showed active-passive behavior of the uncoated 304L substrate and the substrate with the coatings with 21 and 53 at.\% C. Increasing the carbon concentration in the coating changes the shape of the polarization curves, i.e., there is no visible passive area in the anodic range. It can therefore be concluded that in the case of the coating with the $\mathrm{ZrC}$ nanocomposite structure in the amorphous hydrogenated carbon matrix, the oxidation of metallic system components is difficult. For coatings above 53 at. $\%$ C, on polarization curves, there is no clear pitting initiation zone (no breakdown potential was determined). This indicates a high protective potential of these coatings against pitting corrosion in an artificial saliva environment.

All of the $\mathrm{Zr}-\mathrm{C}$ coatings were characterized by a reduction in the corrosion current by an order of magnitude, as well as a slight increase in corrosion potential in relation to the uncoated substrate. Corrosion potential increased with increasing concentration of carbon in the coating. Based on the value of the corrosion current density, the protective performance of the coatings was estimated, which is shown in Table 6 . The protective capacity of all coatings is over $95 \%$. The highest yield among $\mathrm{Zr}-\mathrm{C}$ coatings $(97.7 \%)$ is characterized by the coating with the highest carbon concentration. This property, in conjunction with the absence of a pitting initiation zone on the polarization curve, makes this coating a good candidate for anticorrosive protection of medical grade $304 \mathrm{~L}$ in the environment of human saliva.

\section{Discussion}

On the basis of hydrophobicity and microbiological properties, i.e., bacteriostatic tests and resistance to bacterial adhesion and colonization, it is clear that the antibacterial properties of the $\mathrm{Zr}-\mathrm{C}$ coatings studied grow in accordance with the sequence:

$$
\text { 304L steel } \rightarrow \text { 304L/Zr coating } \rightarrow \text { 304L/Zr-C coating }(<50 \text { at. } \% \text { C) } \rightarrow \text { 304L/Zr-C coating }(>50 \text { at.\% C). }
$$

As demonstrated in the assessment of the antibacterial properties of the $\mathrm{Zr}-\mathrm{C}$ coatings tested, their hydrophobicity plays an important role by determining the contact angle. All tested coatings with $\mathrm{C}$ concentration above 50 at.\% showed a higher contact angle than uncoated 304L steel. Considering the contact angle as a measure of hydrophobicity and at the same time as an assessment of potential antibacterial properties, it can be generally observed that surfaces with $\mathrm{Zr}-\mathrm{C}$ coatings have better antibacterial properties than surfaces of uncoated 304L steel and that coated with Zr. In particular, a rapid increase in antibacterial properties is observed when the carbon concentration in $\mathrm{Zr}-\mathrm{C}$ coatings exceeds 50 at.\%, while practically no significant differences occur in the bacteriostatic tests as well as resistance to bacterial adhesion and colonization. In this context, it is interesting to compare the results of the chemical and phase composition of the coatings carried out using the XPS method and the participation in coatings $\mathrm{sp}^{2}$ and $\mathrm{sp}^{3}$ bonds determined by Raman spectroscopy. First of all, the results of these tests indicate low or no participation of phases with graphite and diamond carbon bonds in coatings with a carbon concentration below 50 at.\%. In turn, in coatings with a carbon concentration above 50 at.\%, based on the analysis of Raman spectra it can be concluded that the carbon has an amorphous form with a dominance of $\mathrm{sp}^{2}$ bonds.

In [40], hydrogenated amorphous carbon $(\alpha-\mathrm{C}: \mathrm{H})$ coatings were produced on PET in an acetylene atmosphere at different working pressures. Coatings differing in the share of $\mathrm{sp}^{3} / \mathrm{sp}^{2}$ bonds were obtained. On the basis of the conducted research it was shown that the adhesion of bacteria to the coatings depends on the structure of the coatings and decreases with decreasing $\mathrm{sp}^{3} / \mathrm{sp}^{2}$ ratio, i.e., an increase in the share of $\mathrm{sp}^{2}$ bonds. Additionally, in [41] it has been proved that the $\mathrm{sp}^{3} / \mathrm{sp}^{2}$ ratio is an important factor affecting the biological response of carbon coatings. As already mentioned, in the test 
results presented in this article, the coatings produced above 50 at.\% $\mathrm{C}$ have the observed advantage of $\mathrm{sp}^{2}$ bonds over $\mathrm{sp}^{3}$ bonds, and these relationships, i.e., the ratio of $\mathrm{sp}^{3} / \mathrm{sp}^{2}$ bonds, do not change with increasing carbon concentration; the antibacterial properties also do not change. These results correspond to the results presented in the cited papers [40,41].

In the context of the obtained results characterizing antibacterial properties, it should also be taken into account that in the tested coatings there is a specific hydrogen concentration due to the fact that $\mathrm{Zr}-\mathrm{C}$ coatings are produced in the $\mathrm{C}_{2} \mathrm{H}_{2}$ atmosphere. In [5], it is stated that the presence of hydrogen in carbon coatings deteriorates their antibacterial activity compared to a coating containing no hydrogen. Bacterial adhesion is an interfacial process and therefore electrostatic and van der Waals forces are most likely responsible for the interaction between material and bacterial surfaces. Due to the presence of hydrogen in the carbon layer, polarized $\mathrm{C}-\mathrm{H}$ bonds are formed, which are promoters of Lifshitz van de Waals forces between the microorganism and the polarized surface of the material [42]. Thus, on the one hand, the advantage of $\mathrm{sp}^{2}$ bonds in the coating promotes its antibacterial effect, while on the other hand, the presence of hydrogen may slightly worsen this effect.

The antibacterial properties of the tested coatings were also examined by analyzing the number of cells attached to the coatings. Both live and dead cells were considered. In these studies, it was found that the number of adsorbed cells, both dead and living, decreases significantly after exceeding 50 at.\% $\mathrm{C}$ compared to uncoated $304 \mathrm{~L}$ steel and that coated with $\mathrm{Zr}$, i.e., as in other tests, the antibacterial properties of coatings increase significantly after exceeding 50 at.\%. In the case of dead cells, studies described in [43-45] suggest that the main mechanism for the death of bacteria is the physical interaction with carbon-based coatings. Carbon aggregates can cause irreversible destruction of the outer cell membrane of bacteria that results in the release of cell contents [43]. The smallest wettability of the coating with a carbon concentration of $\sim 63 \%$ and the smallest roughness observed in SEM images may be the reason for the weakest adhesion, i.e., the highest antibacterial effectiveness, of this coating in relation to some bacterial strains.

In summary, due to biological properties, the tested coatings after exceeding 50 at.\% C are characterized by higher antibacterial properties both compared to uncoated $304 \mathrm{~L}$ steel and to coatings with a lower carbon concentration. Taking into account the possibility of shaping a wide range of mechanical properties of these coatings, especially for coatings with a carbon concentration above 50 at. $\%$, it can be concluded that these coatings are a good candidate for orthodontic applications. An additional argument strengthening this conclusion is the result of corrosion tests. In particular, increasing the carbon concentration in the coating above the stoichiometry results in hindered oxidation of the metallic components of the systems. For these coatings, there is also no clear pitting initiation area on the polarization curves (no breakdown potential was determined). This indicates a high protective potential of these coatings against pitting in the environment of artificial saliva.

\section{Conclusions}

The research presented in the article demonstrates the impact of changing the concentration of carbon in $\mathrm{Zr}-\mathrm{C}$ coatings and related structure changes on the protective potential of these coatings against bacteria and corrosion in the human saliva environment. In particular, based on the results obtained, the following conclusions were drawn:

1. It has been shown that as the concentration of carbon atoms in the coating increases, the content of the phase of carbon unbound to zirconium increases. Raman spectroscopy showed that carbon phase has an amorphous structure with a predominance of bonds with $\mathrm{sp}^{2}$ hybridization.

2. Coatings with carbon concentrations close to 50 at.\% show the highest hardness and Young's modulus. At higher and lower concentrations, there is a sharp decrease in these values.

3. Considering the contact angle as a measure of hydrophobicity and at the same time as an indirect assessment of potential antibacterial properties, it can be generally stated that surfaces coated with $\mathrm{Zr}-\mathrm{C}$ coatings have better antibacterial properties than surfaces of uncoated $304 \mathrm{~L}$ steel. 
4. There is a rapid increase in antibacterial properties when the carbon concentration in $\mathrm{Zr}-\mathrm{C}$ coatings exceeds 50 at.\%. Above this carbon concentration in the coatings, practically no significant differences occur in the bacteriostatic tests as well as resistance to bacterial adhesion and colonization.

5. Corrosion tests showed the high anti-pitting potential of $\mathrm{Zr}-\mathrm{C}$ coatings in the environment of artificial saliva.

6. The wide possibility of shaping the mechanical properties of $\mathrm{Zr}-\mathrm{C}$ coatings in combination with relatively good antibacterial properties after exceeding 50 at. $\% \mathrm{C}$ concentration in coatings and high protective potential of these coatings makes them a good candidate for orthodontic applications.

Author Contributions: Conceptualization, E.C., Ł.S., E.J., K.M. and J.R.; methodology, E.C., E.D., E.J.; validation, A.G., E.D., E.C., P.C. and K.M.; formal analysis, J.R., K.M., E.C.; investigation, E.C., E.D., A.G. and E.J.; data curation, A.G., K.M., E.C., E.D., E.J.; writing-original draft preparation, J.R., K.M., E.C.; writing-review and editing, K.M., J.R., E.J.; visualization, E.J., K.M., P.C.; supervision, J.R., Ł.S.; project administration, A.G.; funding acquisition, A.G., J.R. All authors have read and agreed to the published version of the manuscript.

Funding: This research was funded by the National Science Center, Poland [grant: Opus 11, No. 2016/21/B/ST8/01738] and grant of KUT No. 504.38.05/19.

Conflicts of Interest: The authors declare no conflict of interest.

\section{References}

1. Sharan, D. The problem of corrosion in orthopaedic implant materials. Orthop. Update (India) 1999, 9, 1-5.

2. Shih, C.C.; Shih, C.M.; Su, Y.Y.; Su, L.H.J.; Chang, M.S.; Lin, S.J. Effect of surface oxide properties on corrosion resistance of 316L stainless steel for biomedical applications. Corros. Sci. 2004, 46, 427-441. [CrossRef]

3. Becker, W.; Becker, B.E.; Newman, M.G.; Nyman, S. Clinical and microbiologic findings that may contribute to dental implant failure. Int. J. Oral Maxillofac. Implant. 1990, 5, 1-17.

4. Ding, M.H.; Zhang, H.S.; Zhang, C.; Jin, X. Characterization of ZrC coatings deposited on biomedical 316L stainless steel by magnetron sputtering method. Surf. Coat. Tech. 2013, 224, 34-41. [CrossRef]

5. Zhou, H.; Xu, L.; Ogino, A.; Nagatsu, M. Investigation into the antibacterial property of carbon films. Diam. Relat. Mater. 2008, 17, 1416-1419. [CrossRef]

6. Yao, S.H.; Su, Y.L.; Lai, Y.C. Antibacterial and tribological performance of carbonitride coatings doped with W, Ti, Zr, or Cr deposited on AISI 316L stainless steel. Materials 2017, 10, 1189. [CrossRef]

7. Größner-Schreiber, B.; Herzog, M.; Hedderich, J.; Dück, A.; Hannig, M.; Griepentrog, M. Focal adhesion contact formation by fibroblasts cultured on surface-modified dental implants: An in vitro study. Clin. Oral Implant. Res. 2006, 17, 736-745. [CrossRef]

8. Groessner-Schreiber, B.; Hannig, M.; Dück, A.; Griepentrog, M.; Wenderoth, D.F. Do different implant surfaces exposed in the oral cavity of humans show different biofilm compositions and activities? Eur. J. Oral Sci. 2004, 112, 516-522. [CrossRef]

9. Muzio, G.; Miola, M.; Perero, S.; Oraldi, M.; Maggiora, M.; Ferraris, S.; Vernè, E.; Festa, V.; Festa, F.; Canuto, R.A.; et al. Polypropylene prostheses coated with silver nanoclusters/silica coating obtained by sputtering: Biocompatibility and antibacterial properties. Surf. Coat. Tech. 2017, 319, 326-334. [CrossRef]

10. Marciano, F.R.; Bonetti, L.F.; Mangolin, J.F.; Da-Silva, N.S.; Corat, E.J.; Trava-Airoldi, V.J. Investigation into the antibacterial property and bacterial adhesion of diamond-like carbon films. Vacuum 2011, 85, 662-666. [CrossRef]

11. Lai, C.H.; Chang, Y.Y.; Huang, H.L.; Kao, H.Y. Characterization and antibacterial performance of $\mathrm{ZrCN} /$ amorphous carbon coatings deposited on titanium implants. Thin Solid Films 2011, 520, 1525-1531. [CrossRef]

12. Janvier, G.; Baquey, C.; Roth, C.; Benillan, N.; Belisle, S.; Hardy, J.F. Extracorporeal circulation, hemocompatibility, and biomaterials. Ann. Thorac. Surg. 1996, 62, 1926-1934. [CrossRef]

13. Huang, N.; Yang, P.; Leng, Y.X.; Chen, J.Y.; Sun, H.; Wang, J.; Wang, G.J.; Ding, P.D.; Xi, T.F.; Leng, Y. Hemocompatibility of titanium oxide films. Biomaterials 2003, 24, 2177-2187. [CrossRef]

14. Liu, C.; Lin, G.; Yang, D.; Qi, M. In vitro corrosion behavior of multilayered Ti/TiN coating on biomedical AISI 316L stainless steel. Surf. Coat. Tech. 2006, 200, 4011-4016. [CrossRef] 
15. Hauert, R. An overview on the tribological behavior of diamond-like carbon in technical and medical applications. Tribol. Int. 2004, 37, 991-1003. [CrossRef]

16. Geetha, M.; Singh, A.K.; Asokamani, R.A.; Gogia, A.K. Ti based biomaterials, the ultimate choice for orthopaedic implants-a review. Prog. Mater. Sci. 2009, 54, 397-425. [CrossRef]

17. Gilewicz, A.; Mydłowska, K.; Ratajski, J.; Szparaga, Ł.; Bartosik, P.; Kochmański, P.; Jędrzejewski, R. Structural, mechanical and tribological properties of $\mathrm{ZrC}$ thin films deposited by magnetron sputtering. Vacuum 2019, 169, 108909. [CrossRef]

18. Szparaga, Ł.; Mydłowska, K.; Gilewicz, A.; Ratajski, J. Mechanical and anti-wear properties of multi-module Cr/CrN coatings. Int. J. Surf. Sci. Eng. 2019, 13, 37-49. [CrossRef]

19. Lewin, E.; Wilhelmsson, O.; Jansson, U. Nanocomposite nc-TiC/a-C thin films for electrical contact applications. J. Appl. Phys. 2006, 100, 054303. [CrossRef]

20. Chen, C.S.; Liu, C.P. Diffusion barrier properties of amorphous $\mathrm{ZrCN}$ films for copper metallization. J. Non-Cryst. Solids 2005, 351, 3725-3729. [CrossRef]

21. Sasaki, M.; Kozukue, Y.; Hashimoto, K.; Takayama, K.; Nakamura, I.; Takano, I.; Sawada, Y. Properties of carbon films with a dose of titanium or zirconium prepared by magnetron sputtering. Surf. Coat. Tech. 2005, 196, 236-240. [CrossRef]

22. Martínez-Martínez, D.; López-Cartes, C.; Fernández, A.; Sánchez-López, J.C. Influence of the microstructure on the mechanical and tribological behavior of TiC/aC nanocomposite coatings. Thin Solid Films 2009, 517, 1662-1671. [CrossRef]

23. Liu, B.; Liu, C.; Shao, Y.; Zhu, J.; Yang, B.; Tang, C. Deposition of ZrC-coated particle for HTR with ZrCl4 powder. Nucl. Eng. Des. 2012, 251, 349-353. [CrossRef]

24. Jansson, U.; Lewin, E. Sputter deposition of transition-metal carbide films-A critical review from a chemical perspective. Thin Solid Films 2013, 536, 1-24. [CrossRef]

25. Andersson, M.; Urbonaite, S.; Lewin, E.; Jansson, U. Magnetron sputtering of Zr-Si-C thin films. Thin Solid Films 2012, 520, 6375-6381. [CrossRef]

26. Zheng, Y.F.; Liu, X.L.; Zhang, H.F. Properties of Zr-ZrC-ZrC/DLC gradient films on TiNi alloy by the PIIID technique combined with PECVD. Surf. Coat. Tech. 2008, 202, 3011-3016. [CrossRef]

27. Chu, C.L.; Ji, H.L.; Yin, L.H.; Pu, Y.P.; Lin, P.H.; Chu, P.K. Fabrication, properties, and cytocompatibility of $\mathrm{ZrC}$ film on electropolished NiTi shape memory alloy. Mat. Sci. Eng. C 2011, 31, 423-427. [CrossRef]

28. Chang, Y.Y.; Huang, H.L.; Lai, C.H.; Hsu, J.T.; Shieh, T.M.; Wu, A.Y.J.; Chen, C.L. Analyses of antibacterial activity and cell compatibility of titanium coated with a Zr-C-N film. PLoS ONE 2013, 8, e56771. [CrossRef]

29. Oliver, W.C.; Pharr, G.M. An improved technique for determining hardness and elastic modulus using load and displacement sensing indentation experiments. J. Mater. Res. 1992, 7, 1564-1583. [CrossRef]

30. McCafferty, E. Validation of corrosion rates measured by the Tafel extrapolation method. Corros. Sci. 2005, 47, 3202-3215. [CrossRef]

31. Long, Y.; Javed, A.; Chen, J.; Chen, Z.K.; Xiong, X. Phase composition, microstructure and mechanical properties of $\mathrm{ZrC}$ coatings produced by chemical vapor deposition. Ceram. Int. 2014, 40, 707-713. [CrossRef]

32. Balaceanu, M.; Braic, M.; Braic, V.; Vladescu, A.; Negrila, C.C. Surface chemistry of plasma deposited ZrC hard coatings. J. Optoelectron. Adv. Mater. 2005, 7, 2557-2560.

33. Lewin, E.; Persson, P.A.; Lattemann, M.; Stüber, M.; Gorgoi, M.; Sandell, A.; Ziebert, C.; Schäfers, F.; Braun, W.; Halbritter, J.; et al. On the origin of a third spectral component of C1s XPS-spectra for nc-TiC/a-C nanocomposite thin films. Surf. Coat. Technol. 2008, 202, 3563-3570.

34. Meng, Q.N.; Wen, M.; Mao, F.; Nedfors, N.; Jansson, U.; Zheng, W.T. Deposition and characterization of reactive magnetron sputtered zirconium carbide films. Surf. Coat. Technol. 2013, 232, 876-883. [CrossRef]

35. Voevodin, A.A.; Capano, M.A.; Laube, S.J.P.; Donley, M.S.; Zabinski, J.S. Design of a Ti/TiC/DLC functionally gradient coating based on studies of structural transitions in Ti-C thin films. Thin Solid Films 1997, 298, 107-115. [CrossRef]

36. Ferrari, A.C.; Robertson, J. Interpretation of Raman spectra of disordered and amorphous carbon. Phys. Rev. B 2000, 61, 14095. [CrossRef]

37. Ferrari, A.C.; Robertson, J. Raman spectroscopy of amorphous, nanostructured, diamond-like carbon, and nanodiamond. Philos. Trans. R. Soc. A 2004, 362, 2477-2512. [CrossRef] 
38. Quirynen, M.; Marechal, M.; Busscher, H.J.; Weerkamp, A.H.; Arends, J.; Darius, P.L.; van Steenberghe, D. The influence of surface free-energy on planimetric plaque growth in man. J. Dent. Res. 1989, 68, 796-799. [CrossRef]

39. Bruinsma, G.M.; Van der Mei, H.C.; Busscher, H.J. Bacterial adhesion to surface hydrophilic and hydrophobic contact lenses. Biomaterials 2001, 22, 3217-3224. [CrossRef]

40. Wang, J.; Huang, N.; Pan, C.J.; Kwok, S.C.H.; Yang, P.; Leng, Y.X.; Chen, J.Y.; Sun, H.; Wan, G.J.; Liu, Z.Y.; et al. Bacterial repellence from polyethylene terephthalate surface modified by acetylene plasma immersion ion implantation-deposition. Surf. Coat. Tech. 2004, 186, 299-304. [CrossRef]

41. Liao, T.T.; Zhang, T.F.; Li, S.S.; Deng, Q.Y.; Wu, B.J.; Zhang, Y.Z.; Zhou, Y.J.; Guo, Y.B.; Leng, Y.X.; Huang, N. Biological responses of diamond-like carbon (DLC) films with different structures in biomedical application. Mat. Sci. Eng. C 2016, 69, 751-759. [CrossRef] [PubMed]

42. Gottenbos, B.; Van der Mei, H.C.; Busscher, H.J. Models for studying initial adhesion and surface growth in biofilm formation on surfaces. Method Enzymol. 1999, 310, 523-534.

43. Kang, S.; Pinault, M.; Pfefferle, L.D.; Elimelech, M. Single-walled carbon nanotubes exhibit strong antimicrobial activity. Langmuir 2007, 23, 8670-8673. [CrossRef] [PubMed]

44. Ali, S.S.; Hardt, J.I.; Quick, K.L.; Kim-Han, J.S.; Erlanger, B.F.; Huang, T.T.; Epstein, C.J.; Dugan, L.L. A biologically effective fullerene (C60) derivative with superoxide dismutase mimetic properties. Free Radic. Bio. Med. 2004, 37, 1191-1202. [CrossRef] [PubMed]

45. Tang, Y.J.; Ashcroft, J.M.; Chen, D.; Min, G.; Kim, C.H.; Murkhejee, B.; Larabell, C.; Keasling, J.D.; Chen, F.F. Charge-associated effects of fullerene derivatives on microbial structural integrity and central metabolism. Nano Lett. 2007, 7, 754-760. [CrossRef] [PubMed]

(C) 2020 by the authors. Licensee MDPI, Basel, Switzerland. This article is an open access article distributed under the terms and conditions of the Creative Commons Attribution (CC BY) license (http://creativecommons.org/licenses/by/4.0/). 